\title{
Florence Nightingale's theory and her contributions to holistic critical thinking in nursing
}

\author{
A teoria de Florence Nightingale e suas contribuições para o pensamento crítico holístico na enfermagem \\ La teoría de Florence Nightingale y sus contribuciones al pensamiento crítico holístico en enfermería
}

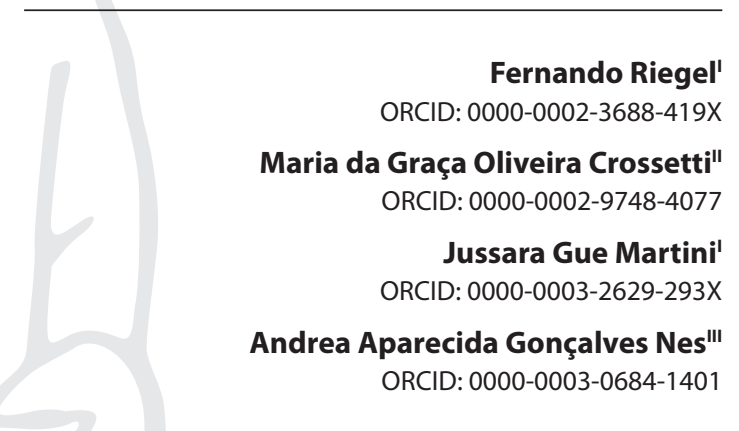

'Universidade Federal de Santa Catarina. Florianópolis, Santa Catarina, Brazil.

"Universidade Federal do Rio Grande do Sul. Porto Alegre, Rio Grande do Sul, Brazil.

"'Lovisenberg Diakonale Høgskole. Oslo, Noruega.

How to cite this article:

Riegel F, Crossetti MGO, Martini JG, Nes AAG. Florence Nightingale's theory and her contributions to holistic critical thinking in nursing. Rev Bras Enferm. 2021;74(2):e20200139. doi: http://dx.doi.org/10.1590/0034-7167-2020-0139

\section{Corresponding author:}

Fernando Riegel

E-mail: fernandoriegel85@gmail.com

EDITOR IN CHIEF: Antonio José De Almeida Filho ASSOCIATE EDITOR: Rafael Silva

Submission: 04-26-2020 Approval: 09-27-2020

\begin{abstract}
Objective: to reflect on Florence Nightingale's legacy and describe her contributions to critical holistic thinking in nursing. Methods: this is a theoretical reflection, for which scientific productions on Florence Nightingale's environmental theory, as published in national and international journals, were based. Results: Florence Nightingale's philosophy and teachings emphasize that the nurse must use her brain, heart and hands to create healing environments to care for the patient's body, mind and spirit. Nursing, since the time of Nightingale, has been building the holistic paradigm, in all schools of thought, with a view to a humanistic approach to the human being in their indivisible relationship with the environment. Final considerations: Florence's contributions to holistic critical thinking in nursing are evident, constituting nurses' differential in clinical practice.

Descriptors: Critical Thinking; Nursing Theory; History of Nursing; Nursing Care; Nursing.
\end{abstract}

\section{RESUMO}

Objetivo: refletir sobre o legado de Florence Nightingale e descrever suas contribuições para o pensamento crítico holístico na enfermagem. Métodos: trata-se de uma reflexão teórica, para a qual serviram de base produções científicas sobre a teoria ambientalista de Florence Nightingale, publicadas em periódicos nacionais e internacionais. Resultados: a filosofia e os ensinamentos de Florence Nightingale enfatizam que a enfermeira deve usar o cérebro, o coração e as mãos na criação de ambientes de cura, para cuidar do corpo do paciente, de sua mente e de seu espírito. A enfermagem, desde a época de Nightingale, vem construindo o paradigma holístico, em todas as escolas de pensamento, com vistas a uma abordagem humanística do ser humano em sua indivisível relação com o ambiente. Considerações finais: as contribuições de Florence ao pensamento crítico holístico na enfermagem são evidentes, constituindo o diferencial do enfermeiro na prática clínica.

Descritores: Pensamento Crítico; Teoria de Enfermagem; História da Enfermagem; Cuidados de Enfermagem; Enfermagem.

\section{RESUMEN}

Objetivo: reflexionar sobre el legado de Florence Nightingale y describir sus contribuciones al pensamiento crítico holístico en enfermería. Métodos: se trata de una reflexión teórica, para la cual se basaron producciones científicas sobre la teoría ambiental de Florence Nightingale, publicadas en revistas nacionales e internacionales. Resultados: la filosofía y las enseñanzas de Florence Nightingale enfatizan que la enfermera debe usar su cerebro, corazón y manos para crear ambientes curativos para cuidar el cuerpo, la mente y el espíritu del paciente. La enfermería, desde la época de Nightingale, ha ido construyendo el paradigma holístico, en todas las escuelas de pensamiento, con miras a un acercamiento humanista al ser humano en su relación indivisible con el medio ambiente. Consideraciones finales: las contribuciones de Florence al pensamiento crítico holístico en enfermería son evidentes, constituyendo el diferencial de la enfermera en la práctica clínica.

Descriptores: Pensamiento; Teoría de Enfermería; Historia de la Enfermería; Atención de Enfermería; Enfermería. 


\section{INTRODUCTION}

The year 2020 marks the bicentenary of the birth of Florence Nightingale, the forerunner of modern nursing, i.e., the ideal time to analyze and reflect on her contributions and the impact on nursing professionalization. Based on Dewey's premise, "The past is key to understanding the present". This theoretical reflection proposes to describe Florence's contributions to holistic critical thinking in nursing ${ }^{(1)}$.

Nightingale left a legacy of teachings and cornerstones that underpin the profession to this day. Her idealism runs through the historical trajectory of nursing through the records left, as current as 200 years ago. The alignment of current trends with Nightingale's theory and philosophy is impressive.

Florence's contributions are prominent in international literature, especially when her fundamental principle is discussed in her writings, i.e., healing (healing process or healing act), representing the gathering of all aspects of the body, mind and spirit, to achieve and maintain the integration of a balance, which denotes holistic nursing care ${ }^{(2-4)}$. Nightingale, in the distinction between therapy and healing, explains that therapy can always be instituted, but healing is not always possible. Removing the signs and symptoms of a disease does not heal the disease, and involves only one dimension of care, the physical dimension, leaving the spiritual dimension in the background ${ }^{(5-8)}$.

In this sense, it is important to highlight that Nightingale introduced, in the context of care, colors, light, music, pets, exercise, flowers as aspects to be emphasized in a favorable environment in search of healing, reaffirming the bases of environmental theory and the premise that the environment influences people's health ${ }^{(5)}$.

It is stated that, in order to become a nurse sensitive to holism, it requires the understanding, in the care encounter in which it is present, of all the facets presented by patients. This genuine presence requires nurses to first understand all aspects of themselves ${ }^{(3)}$; in other words, it is paramount, in the care process, that nurses also understand themselves in their entirety to, from that, be able to understand patients in all their needs, be they physiological or spiritual.

In this way, spirituality in nursing is one of the pillars of holistic nursing, with emphasis on characteristics such as: harmony, balance and interaction in a functional totality of its aspects; qualities and potential of individuals and/or collectivity; person-centered or community-centered care, focusing on it as an indivisible unit and in constant interaction with the environment; comprehensive attention to the individual's and/or the community's basic human needs, addressing biopsychosocial and spiritual aspects; use of technology applied to human health; development of natural methods in order to improve their health ${ }^{(6-7)}$.

Currently, nurses are being challenged to boost Florence's ideals through critical thinking, aiming to provide humane and competent care based on the best scientific evidence against the backdrop of unprecedented changes, which have occurred worldwide, requiring nurses to be able for critical and holistic thinking in clinical decisionmaking and care management in different contexts of practice. Thus, it is important to highlight the fundamental concepts of the course proposed by Nightingale in the 1850s. Her precepts, created with wisdom and from an expanded world view, revolutionary for the time, echo through the decades, influencing science nurses until today and that show their contributions to the constitution of nurses' holistic critical thinking ${ }^{(2)}$.

\section{OBJECTIVE}

This study aimed to reflect on Florence Nightingale's legacy and describe her contributions to critical holistic thinking in nursing.

\section{METHODS}

This is a theoretical reflection article, for which scientific productions on Florence Nightingale's environmental theory, published in national and international journals, were based. For this, a search was carried out in national and international databases, with the objective of selecting published studies on the contributions of Florence's environmental theory to holistic critical thinking in nursing.

Moreover, bibliographic references were used for the theoretical basis about critical thinking and Florence Nightingale's theory. Based on the selected scientific productions, a careful reading was carried out in order to identify and synthesize the main contributions of environmental theory, being organized and presented in three sections: Florence Nightingale's legacy: central principles and concepts of environmental theory; Florence Nightingale: repercussions of her teachings for modern nursing; Holistic nursing and nurses' holistic critical thinking.

\section{RESULTS}

\section{Florence Nightingale's legacy: central principles and con- cepts of environmental theory}

Nightingale's life trajectory was immersed in complexity, partially revealed in her 14,000 letters and 100 books, reports, and bulletins. The precursor of nursing believed that nursing was her call from God, her curious and passionate mind for nursing and her relentless desire to transform opened doors challenging the social context, in which she encountered persistent opposition, as she was always a visionary and courageous woman. Furthermore, she advocated that patients receive civilized care, regardless of the social situation experienced ${ }^{(5)}$.

Faced with this premise, this reflection article seeks to provoke the reader to reflect on Florence's trajectory, examining her legacy with the following question: does Nightingale's theory and principles contribute to the development of nurses' holistic critical thinking today? The answer is affirmative, since, in this context, holistic nursing is based on nursing knowledge, theories, research, doing mediated by experience, intuition and creativity. Additionally, "it includes as a function and objective of nursing care and contribute to the healing of people in their entirety from birth to death", as recommended by Florence Nightingale ${ }^{(6)}$.

In 1859, Florence wrote Notes on Hospital, and, in 1860, Notes on Nursing. These compendiums explained hygiene standards, treatment of injuries, ventilation and other concepts necessary for building nursing science. Her standards on nutrition, sleep and exercise continue to guide health promotion to the present day ${ }^{(3)}$. 
The three principles of Florence's environmental theory are healing, leadership, and global action. The principle considered basic was healing, and the secondary ones, leadership and global action, were principles necessary to support healing at its deepest level. With regard to Florence's educational model, one must take into account the fact that it is based on the anticipation of care and attention to patients' needs, providing guidance for nurses to perform activities in order to meet patients' needs ${ }^{(8)}$.

Florence Nightingale's environmental theory is based on five points, which she believed to be essential to obtain a healthy home, such as clean water and air, basic sanitation, cleanliness and light, as she believed that a healthy environment was fundamental for healing. In her time, she reported that noise was harmful and disturbed the rest of individuals, so the conversation of caregivers should be avoided, as well as agitation, unnecessary questions. On the other hand, Florence recommended nutritious food, beds and appropriate bedding and personal hygiene for individuals ${ }^{(8)}$.

In this theoretical and practical context, nursing was seen as a means of "putting the individuals' structure in such a state that they have no disease or can recover from the disease", placing individuals in a condition in which nature can preserve or recover health - preventing or curing illness or injury. Health, according to Florence, is defined as the ability of individuals to properly use all their skills and competencies in the perspective of caring for themselves and others ${ }^{(3)}$.

Florence defended a solid knowledge base in nursing and anchored in principles; if this were not possible, it would be like building a house with a weak foundation, i.e., it will fall. This premise becomes even more current when applied in nursing education, i.e., nurses trained with strong bases and principles will have subsidies to provide quality care, applying their critical thinking to making accurate decisions for the benefit of patients under their responsibility. Florence argued that nurses should accurately observe their patients and report the real state of health in an orderly manner to the physician ${ }^{(5)}$.

Based on Nightingale's principles, we can evidence her search for respect for humanity and social justice, as she defended respect for the human person regardless of social class, physical disabilities, hygiene conditions or occupation. While her family sought to include her in an elitist culture, her spirituality called her to serve ordinary people. For Nightingale, a true nurse should renounce class distinctions and always focus on the person ${ }^{(2)}$.

Faced with soldiers wounded in the Crimean War, she insisted that each soldier be treated with dignity and kindness, a radical departure from military custom. In light of this, we highlight the efforts of hospital institutions to provide humane and patient-centered care. We can now observe the focus on safety and meeting users' real health needs, through quality programs and through direct care provided by nurses, proposing to be closer to their patients ${ }^{(5)}$.

\section{Florence Nightingale: repercussions of her teachings for modern nursing}

Modern nursing has (re) invented itself; however, it has retained numerous principles of Florence's environmental theory in its scientific bases. It also incorporated new technologies, to guarantee the execution of human and singular care to human beings, always guided by the science and art inherited from Florence Nightingale, prioritizing the comfort, the technique and the environment suitable for healing patients.

Nightingale's commitment to staying with patients in times of suffering is the very basis of patient-centered care, which becomes a very current and necessary principle for the full recovery of patients ${ }^{(5)}$. For this, individualized care to patients' needs needs to be implemented. Currently, such care, also called nursing interventions or activities, ended up being researched and polished. They were cataloged in the form of international classification of results and interventions, based on the standardized language of nursing diagnoses, structured from the real or potential problems of individuals, who need nursing assistance.

Florence addressed the organization of care delivery with a focus on obtaining a healing; currently, we can find this determination in the Nursing Process, understood as a methodological instrument used by nurses to organize and plan nursing care and structured in five stages: research, nursing diagnoses, planning, implementation, and assessment.

Modernity has brought significant advances, which have strained the qualification of nurses' being and doing; the insertion of new care and teaching technologies has been widely implemented. In this direction, Florence's teachings have left their mark, influencing the nursing routine, as it has always emphasized the importance of nurses' commitment to care, as well as learning based on practice.

Numerous ways of doing nursing are currently presented as novelties, denoting the rescue of innovations that Florence, in her time, created and implemented, only with the difference of today taking on a new guise, such as risk stratification, prevention and control of infections, cleanliness, fresh air, comfort, considering that the environment directly affects the health of individuals through music, colors. The possibility of inserting pets or therapeutic animals are practices indicated and implemented by Florence ${ }^{(8)}$.

Therefore, in this process, innovating in nursing presupposes taking into account the principles and concepts learned from Nightingale, in addition to the theories proposed by countless nursing theorists. Care territories and contexts should be sought to, in this way, modify forms of care devoid of scientific knowledge and the necessary structure for quality nursing care.

Thus, memories of the past related to the origins of care science must be preserved in order to understand and modify the being and doing of nurses in the present and in the future. This is the main objective of modern nursing. In this context, we highlight the importance of holistic nursing and the development of critical thinking, so urgent today, in order to qualify teaching, research, and care ${ }^{(2)}$.

One of the greatest challenges of modern nursing is to meet human needs in their entirety. These will be better identified by nurses who think and practice nursing in a holistic perspective, developing professional training focused on critical thinking in their care contexts and practices. Thus, said innovations in nursing will consist of the necessary and pressing rescue of Florence's teachings ${ }^{(2-3)}$.

Thus, this brings us to the current world health scenario that we are experiencing with regard to the health situation in the midst of Florence's bicentennial. The scientific, human, ethical 
and social commitment of nursing science in times of pandemic is reaffirmed, recognizing the value of philosophy which, in turn, is even more necessary to maintain her environmental theory principles today. It should be explored in depth in the spaces of training and assistance, providing the basis for supporting nursing education and the development and practical application of critical thinking of future nurses, aiming at qualitatively intervening in human care with a view to prevention and healing diseases in general. Thus, Florence Nightingale's principles can directly reflect on the process of training and care in different contexts of teaching and care.

\section{Holistic nursing and nurses' holistic critical thinking}

Holistic nursing is based on nursing knowledge, theories, research, doing mediated by experience, as well as intuition and creativity $^{(6)}$. In this perspective, nursing practice incorporates theory, practice and subjective aspects, as well as intuition and creativity, which are decisive in how this care model will be constituted.

Florence's legacy with regard to holistic nursing, as well as critical thinking, is evident when we analyze the historical path of meeting humanity'needs, and has been at the forefront in providing care and comfort to patients. Moreover, nursing was also concerned with health education for the population. Florence encouraged her students to consider cultural and religious diversity, as well as the values, needs and concerns of individuals in their uniqueness, without neglecting the economic and social aspects that involve care ${ }^{(5)}$.

Florence's historical trajectory shows the importance of nurses capable of thinking critically and holistically to deal with situations of adversity, as was the case in the Crimean War. Florence experienced scenarios of uncertainties, adversities and care contexts for which she needed to apply her highly developed critical thinking to the feminine patterns and patterns of her time ${ }^{(3)}$.

Holistic critical thinking can be defined as thinking with quality, i.e., a judgment process centered on deciding what to believe or what to do. In doing so, the critical thinker should not be negative or cynical, but reflective and balanced, requiring people to express some kind of reason or basis for whatever they are saying ${ }^{(9)}$.

According to Florence's view, nurses should think critically about patient care, doing what was appropriate and necessary to help them heal, reinforcing the importance of developing in nurses the critical and holistic way of thinking in the daily life of be and do nursing ${ }^{(8)}$.

Starting from this way of thinking, at that time, evidence-based practice was carried out in a very healthy way for the performance of nursing procedures and care, as research was still scarce. Even so, Florence can be considered a pioneer in conducting research on evidence-based practice and the application of critical thinking. Florence's environmental theory strongly supported nursing and also for the development of critical thinking, contributing to evidence-based nursing practice and beyond these very important aspects of nurses' training and clinical practice ${ }^{(5,8)}$.

Like Florence, it is worth highlighting other nursing theorists, such as Watson, Horta, King and Leninger, who impacted society by considering not only the physical aspects of a human being, but also the interconnection between each individual's body, mind and spirit. It must be considered that, in the last three decades, nursing has gone from a model focused on physiological and scientific aspects to a model focused on nursing science, care and healing, seeking to consider the cultural aspects, values and beliefs connected to the act to care ${ }^{(10)}$.

In Brazil, we can describe this movement as a paradigm shift from a biomedical-technicist model to a care model based on the art and science of technical-scientific and humanistic care ${ }^{(10)}$. This movement boosted the emphasis on Florence Nightingale's philosophy and teachings, awakening in nurses the capacity and a need to think holistically using the brain, heart and hands in creating healing environments, in order to effectively take care of the trinomial dimensional body-mind-spirit.

Accordingly, it is possible to note a critical thinking strongly influenced by the contributions of Florence's legacy, which direct nurses towards a comprehensive and humanistic approach, in which the ability to listen and to consider a person in their entirety predominates. In this direction, nurses who develop holistic critical thinking in nursing training will have better performance by applying cognitive, behavioral and habits of the mind and, consequently, Florence Nightingale's principles and theory. In this regard, it will be possible to care for individuals as a unique human being, i.e., singular, in order to consider the needs related to the physical body (physiological aspects), the mind (emotional aspects) and the spirit (spiritual aspects) ${ }^{(10)}$.

The scarcity of research published in Brazil addressing the influence of Nightingale's theory on nurses' holistic critical thinking is one of the limitations of this reflection. This denotes a knowledge gap to be filled, given the importance of this theme for nursing education and care. Concerning the contributions of this study, the possibility of impacting professional practice through knowledge and recognition of Florence's legacy for training and professional practice is highlighted, in addition to enabling students and nurses to understand Nightingale's theory.

\section{FINAL CONSIDERATIONS}

This theoretical reflection ends with evidence of the fundamental importance of the contributions of Florence Nightingale's legacy to critical thinking in nursing. Moreover, it is seen that her theory is decisive in filling the knowledge gaps related to the holistic dimension in carrying out the nursing process, aiming at accurate clinical decision-making of students and nurses. It is imperative that nurses apply Nightingale's holistic philosophy and assumptions in nursing, as patients expect compassion, in addition to specialized nurses focused on the totality of human needs.

Nightingale's legacy allows us to meet these expectations, as her philosophy includes encouraging self-care, art and nursing science, covering related theories, in addition to research and ethics. Nightingale demonstrated by example in her trajectory, spreading, in her scientific productions that her fundamental principle was to care with a focus on prevention and healing through the process that unites all the singular dimensions that constitute the whole of individuals to achieve and maintain integration and balance. Thus, to guarantee this focus on nursing training, the commitment that teaching and caring are verbs and actions to be conjugated beyond the discourse and carried out in the genuine practice of being and doing by nurses is reaffirmed. 


\section{REFERENCES}

1. Dewey J. Democracy and education. New York (NY): Free Press (Reprint), 2004.

2. American Holistic Nurses Credentialing Corporation. American Holistic Nurses Association. Foundations. Competencies, and curriculum guidelines for basic to doctoral holistic nursing education[Internet]. 2017[cited 2020 Jul 5];1(1):1-55. Available from: https://www.ahncc.org/ wp-content/uploads/2018/10/Foundations-Competencies-Curricular-Guidelines.pdf

3. Nightingale F. Notes on nursing: what it is, and what it is not. Philadelphia (PA): J. B. Lippincott, 1859/1992.

4. Healing. In: Dictionary Cambridge. Grã-Bretanha, Cambridge (GB-C): Cambridge University Press; 2020.

5. Kalb KA, Conner-Von SO. Holistic Nursing Education: Teaching in a holistic way. Nurs Educ Perspect. 2019;40(3):162-64. https://doi. org/10.1097/01.NEP.0000000000000405

6. American Holistic Nurses Association (AHNA). What is Holistic Nursing. [Internet]. 2020. [cited 2020 Jul 5]. 1(1)-1-2. Available from: http:// ahna.org/about/whatis.html

7. Lopes ND, Nóbrega MML. Holismo nos modelos teóricos de enfermagem. Rev Bras Enferm. [Internet]. 1999[cited 2020 Jul 5];52(2):233-42. Available from: https://www.scielo.br/pdf/reben/v52n2/v52n2a10.pdf

8. McEwen M, Willis EM. Theoretical Basis for Nursing. 5 ed. Alphen aan den Rijn (NL): Wolters Kluwer; 2018. 624 p.

9. Facione PA, Gittens CA. Think Critically. Chapter 1. Califórnia (EUA): Pearson Education; 2016. 418 p.

10. Riegel F, Crossetti MGO, Siqueira DS. Contributions of Jean Watson's theory to holistic critical thinking of nurses. Rev Bras Enferm. 2018;71(4):2072-6. http://dx.doi.org/10.1590/0034-7167-2017-0065 